\title{
Penerapan Tutor Sebaya Dalam Implementasi Strategi CIRC Berbasis Active Learning Untuk Meningkatkan Hasil Belajar Siswa Pada Mata Pelajaran Sistem Komputer di SMKN 5 Makassar
}

\author{
Ayu Widya Listari ${ }^{1}$, Riana T. Mangesa ${ }^{2}$, Muliadi $^{3}$ \\ Program Studi Pendidikan Teknik Informatika dan Komputer \\ Universitas Negeri Makassar \\ layuwidyalistari@gmail.com \\ ${ }^{2}$ Rianamangesalyahoo.com \\ ${ }^{3}$ Muliadi7404@unm.ac.id
}

\begin{abstract}
Abstrak - Penelitian ini bertujuan untuk meningkatkan hasil belajar siswa melalui penerapan Tutor Sebaya dan Implementasi Strategi CIRC pada mata pelajaran Sistem Komputer siswa kelas X TKJ SMK Negeri 5 Makassar yang berjumlah 34 orang. Penelitian ini merupakan penelitian tindakan kelas yang terdiri atas empat tahapan yaitu perencanaan tindakan, pelaksanaan tindakan, evaluasi dan refleksi. Penelitian ini dilaksanakan dalam dua siklus yaitu masing-masing siklus terdiri atas tiga kali pertemuan. Data dikumpulkan menggunakan angket, lembar observasi, tes tertulis dan dokumentasi. Teknik analisis data yang digunakan adalah analisis statistik deskriptif. Hasil penelitian yang ditemukan ini menunjukkan penerapan Tutor Sebaya dan Implementasi strategi CIRC dapat meningkatkan hasil belajar siswa kelas X TKJ SMK Negeri 5 Makassar. Hal ini berdasarkan nilai hasil belajar yang di peroleh siswa dari Siklus I ke Siklus II mengalami peningkatan.
\end{abstract}

Kata Kunci : Penerapan Tutor Sebaya, Strategi CIRC, Hasil Belajar, Sistem Komputer

\section{PENDAHULUAN}

Secara umum Pengertian Pendidikan adalah sebagai usaha sadar dan terencana untuk mewujudkan suasana belajar dan proses pembelajaran untuk peserta didik secara aktif mengembangkan potensi dirinya. Secara sederhana, pengertian pendidikan adalah proses pembelajaran bagi peserta didik untuk dapat mengerti, paham, dan membuat manusia lebih kritis dalam berfikir. Menurut Feni (2014: 13) Pendidikan merupakan bimbingan atau pertolongan yang diberikan oleh orang dewasa kepada perkembangan anak untuk mencapai kedewasaan dengan tujuan agar anak cukup cakap melaksanakan tugas hidupnya sendiri tidak dengan bantuan orang lain.

Undang-undang No. 20 Tahun 2003 tentang sistem pendidikan nasional secara tegas menyatakan bahwa Pendidikan merupakan usaha sadar dan terencana untuk mewujudkan suasana belajar dan proses pembelajaran agar siswa secara aktif mengembangkan potensi dirinya untuk memiliki kekuatan spiritual keagamaan, pengendalian diri, kepribadian, kecerdasan, akhlak mulia, serta keterampilan yang diperlukan dirinya, masyarakat, bangsa, dan negara (Sistem Pendidikan Nasional pasal 1 ayat 1 2003: 2).

Komponen utama yang harus dipenuhi dalam proses belajar mengajar yaitu siswa, guru, tujuan pembelajaran, model, metode pembelajaran, media dan evaluasi. Tujuan pembelajaran yang diinginkan tentunya yang optimal, untuk itu ada beberapa hal yang perlu diperhatikan oleh guru, salah satunya adalah model pembelajaran (Mangesa, R. T; Mappaloteng, A. M, 2019).

Guru sebagai ujung tombak pendidikan diharapkan dapat memotivasi siswa untuk berperan aktif dalam proses pembelajaran diri sendiri (self instructional) sehingga mencapai kompetensi minimal yang telah ditentukan dan menghadirkan pembaharuan dalam proses pembelajaran untuk meningkatkan mutu pendidikan. Pendidikan harus diarahkan untuk mengembangkan potensi yang dimiliki peserta didik dengan upaya pembentukan peserta didik yang tanggap terhadap lingkungan dan peka terhadap adanya perubahan dalam pendidikan. Berhasil tidaknya suatu tujuan pendidikan bergantung kepada bagaimana proses belajar mengajar dirancang dan disajikan.

Berdasarkan realita atau fenomena yang terjadi di SMK Negeri 5 Makassar yaitu rendahnya hasil belajar siswa dikarenakan proses pembelajaran masih menggunakan metode ceramah. Metode ceramah merupakan metode di mana pendidik cenderung menguasai pembelajaran, sehingga siswa tidak termotivasi untuk ikut aktif dalam mengikuti proses pembelajaran. Selain itu, proses belajar mengajar di kelas hanya menjadi aktivis guru saja. Dalam kegiatan belajar mengajar, interaksi hanya berjalan satu arah, yakni dari guru saja (teacher centered learning). Motivasi belajar siswa juga rendah karena pendidik tidak memfasilitasi siswa untuk mengembangkan kemampuan berpikirnya sehingga lebih termotivasi untuk belajar.

SMK Negeri 5 Makassar merupakan Sekolah Menengah Kejuruan yang membuka program keahlian Teknologi Komputer dan Jaringan yang didalamnya terdapat mata pelajaran Sistem Komputer. Pelajaran Sistem Komputer merupakan salah satu mata pelajaran keahlian yang diajarkan pada siswa kelas X TKJ. Di SMK Negeri 5 Makassar, menetapkan Kriteria Ketuntasan Minimal (KKM) untuk Mata Pelajaran Sistem Komputer di jurusan TKJ pada tahun 2019/2020 yakni 75. Siswa dengan nilai di atas 75 dinyatakan lulus sedangkan siswa dengan nilai di bawah 75 dinyatakan remedial.

Berdasarkan hasil observasi pada pembelajaran sistem komputer di SMK Negeri 5 Makassar, ditemukan kondisi dimana guru kurang kreatif dan inovatif dalam penggunaan metode pembelajaran. Maka dari itu, salah satu alternatif cara yang dapat digunakan untuk meningkatkan hasil belajar siswa adalah dengan menerapkan metode dan strategi yang dapat menarik perhatian dan minat belajar siswa, melibatkan siswa secara langsung, menuntut peran siswa untuk aktif dan terlebih lagi meminimalisir kesenjangan hasil belajar diantara siswa yaitu penerapan tutor sebaya dalam implementasi strategi $C I R C$

Rumusan masalah dalam penelitian ini adalah Bagaimana Penerapan Tutor Sebaya dalam implementasi strategi Cooperative Integrated Reading and Composition (CIRC) berbasis active 
learning untuk meningkatkan hasil belajar siswa di SMKN 5 Makassar ? dan Apakah Penerapan Tutor Sebaya dalam implementasi strategi Cooperative Integrated Reading and Composition (CIRC) berbasis active learning dapat meningkatkan hasil belajar siswa di SMKN 5 Makassar?

\section{LANDASAN TEORI}

A. Tutor Sebaya

Tutor sebaya adalah bimbingan atau bantuan yang diberikan kepada orang lain dengan umur yang sebaya. Belajar bersama dalam kelompok dengan tutor sebaya merupakan salah satu ciri pembelajaran berbasis kompetensi, melalui kegiatan berinteraksi dan komunikasi, siswa menjadi aktif belajar, mereka menjadi efektif. Kerjasama dalam kelompok dengan tutor sebaya dapat dikaitkan dengan nilai sehingga kerjasama makin intensif dan siswa dapat mencapai kompetensinya. Salah satu tipe pembelajaran kooperatif adalah tipe tutor sebaya. Tutor adalah orang yang membimbing dalam proses pembelajaran kelas tutorial kepada peserta didik secara langsung, kegiatan yang dilakukan oleh seorang tutor adalah kegiatan tutorial atau tutoring (Andriyansah dkk, 2014: 3).

Menurut Branley dalam Riska Dian Pramesti (2014), ada dua model dasar dalam menyelenggarakan proses belajar dengan tutor, yaitu:

1) Student to student.

2) Tutor to group.

Menurut Dale H. Schunk (2012:199-201) tahapan pembelajaran dengan tutor sebaya pada umumnya mengikuti pola sebagai berikut:

1. Guru menyusun kelompok belajar. Setiap kelompok beranggotakan 3 atau 4 orang yang memiliki kemampuan beragam.

2. Guru melatih tutor dalam materi yang akan dipelajari oleh kelas dan menjelaskan latihan serta evaluasi yang akan dilakukan.

3. Guru menjelaskan materi pelajaran secara ringkas pada semua peserta didik dan memberikan kesempatan tanya jawab.

4. Guru memberikan tugas yang harus dikerjakan dan tata cara melakukan evaluasi.

5. Tutor sebaya membantu temannya dalam mengerjakan tugas dan memberikan penjelasan materi yang belum dipahami oleh temannya dalam satu kelompok.

6. Guru mengamati aktivitas belajar dan memberi penilaian kompetensi.

7. Guru, tutor, dan peserta didik memberikan evaluasi proses belajar mengajar untuk menetapkan tindak lanjut kegiatan putaran berikutnya.

B. Strategi Cooperative Integrated Reading and Composition (CIRC)

Sugiyanto (dikutip Mangesa, R. T.; Mappaloteng, A. M. 2019), yang berfokus pada penggunaan kelompok kecil, untuk bekerja sama dalam memaksimalkan kondisi belajar untuk mencapai tujuan belajar. Menurut Hartono (2013) menyatakan bahwa strategi dalam dunia pendidikan diartikan sebagai sebuah proses perencanaan yang memuat serangkaian kegiatan yang telah didesain dengan baik untuk mencapai tujuan pendidikan. Slavin (dikutip Halimah, 2014: 32), model pembelajaran CIRC memiliki delapan komponen. Kedelapan komponen tersebut sebagai berikut

1. Teams, yaitu pembentukan kelompok heterogen yang terdiri atas 4 atau 5 siswa.
2. Placement test, misalnya diperoleh dari rata-rata nilai ulangan harian sebelumnya atau berdasarkan nilai rapor agar guru mengetahui kelebihan dan kelemahan siswa pada bidang tertentu.

3. Student creative, melaksanakan tugas dalam suatu kelompok dengan menciptakan situasi dimana keberhasilan individu ditentukan atau dipengaruhi oleh keberhasilan kelompoknya.

4. Team study, yaitu tahapan tindakan belajar yang harus dilaksanakan oleh kelompok dan guru memberika bantuan kepada kelompok yang membutuhkannya.

5. Team scorer and team recognition, yaitu pemberian skor terhadap hasil kerja kelompok dan memberikan kriteria penghargaan terhadap kelompok yang berhasil secara cemerlang dan kelompok yang dipandang kurang berhasil dalam menyelesaikan tugas.

6. Teaching group, yakni memberikan materi secara singkat dari guru menjelang pemberian tugas kelompok.

7. Facts test, yaitu pelaksanaan test atau ulangan berdasarkan fakta yang diperoleh siswa.

8. Whole-class units, yaitu pemberian rangkuman materi oleh guru di akhir waktu pembelajaran dengan strategi pemecahan masalah.

\section{Hasil Belajar}

Kegiatan belajar dan mengajar sasarannya adaah hasil belajar, jika cara dan motivasi belajar baik, maka diharapkan hasil belajarnya juga baik (Mappeasse, Y. M., 2009). Hasil belajar yang secara garis besar dibagikan menjadi tiga ranah, yaitu ranah kognitif, ranah afektif, dan ranah psikomotoris.

\section{Sistem Komputer}

Sistem berasal dari bahasa Latin (Systema) dan bahasa Yunani (sustema) adalah suatu kesatuan yang terdiri dari komponen atau elemen yang dihubungkan bersama untuk memudahkan aliran informasi materi atau energy. Istilah ini sering dipergunakan untuk menggambarkan suatu set entitas yang berinteraksi, di mana suatu model matematika seringkali bisa dibuat. Sistem juga merupakan kesatuan bagian-bagian yang saling berhubungan yang berada dalam suatu wilayah serta memiliki item-item penggerak.

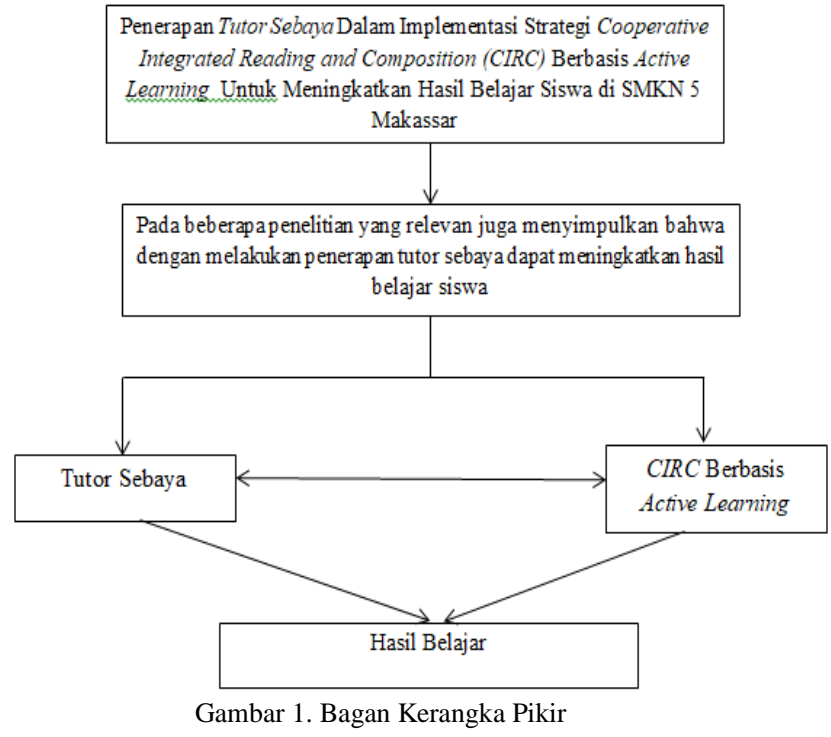




\section{METODE PENELITIAN}

A. Jenis Penelitian

Jenis penelitian yang akan digunakan adalah Penelitian Tindakan Kelas (PTK) atau Classroom Action Research (CAR). Penelitian tindakan kelas (PTK) adalah penelitian tindakan yang dilakukan dengan tujuan memperbaiki mutu praktik pembelajaran di kelas. Tujuan utama penelitian ini ialah untuk memecahkan permasalahan nyata yang terjadi di kelas dan meningkatkan kegiatan nyata guru dalam kegiatan pengembangan profesinya.

B. Waktu dan Tempat Penelitian

Waktu pelaksanaan penelitian ini dilakukan mulai bulan Oktober sampai dengan November 2019. Adapun tempat penelitian ini dilaksanakan di SMKN 5 Makassar yang berlokasi di Jl. Sunu No. 162, Kalukuang, Kec. Tallo, Kota Makassar, Sulawesi Selatan.

\section{Prosedur Penelitian}

Prosedur penelitian yang digunakan dalam penelitian ini adalah model spiral dari Kemmis dan Taggart yang dikutip oleh Suharsimi Arikunto dalam bukunya "Penelitian Tindakan Kelas", yang membagi prosedur penelitian tindakan dalam empat tahap kegiatan pada satu siklus, yaitu: perencanaan, pelaksanaan, pengamatan dan refleksi. Model Suharsimi Arikunto dapat dilihat pada Gambar di bawah ini:

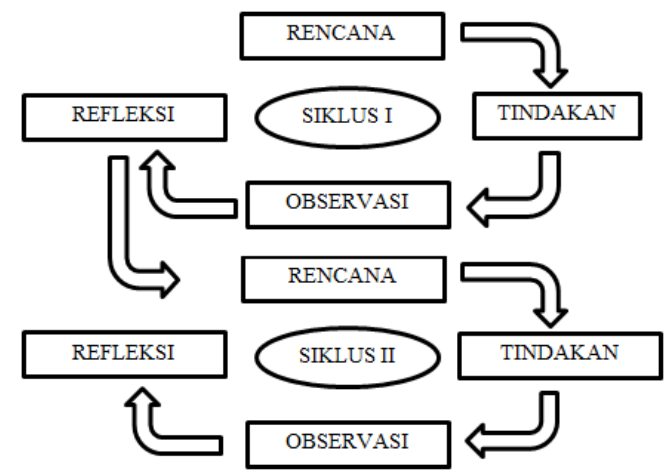

Gambar 2. Prosedur Penelitian

D. Subjek Penelitian

Subjek dalam penelitian ini adalah siswa kelas X TKJ yang berjumlah 35 orang di SMKN 5 Makassar tahun ajaran 2019/2020.

E. Definisi Operasional Variabel

Definisi Operasional Variabel adalah suatu variabel dengan mengkategorikan sifat-sifat menjadi elemen yang dapat diukur.

F. Teknik Pengumpulan Data

Teknik pengumpulan data yang digunakan dalam penelitian sebagai berikut :

a. Angket

Metode pengumpulan data yang digunakan dalam penelitian ini adalah metode angket atau kuesioner.

b. Dokumentasi

Dokumentasi yang digunakan dalam penelitian ini meliputi silabus, RPP dan profil sekolah.

c. Teknik tes

Pada teknik ini dilakukan tes kemampuan awal, tes Siklus 1 dan tes Siklus II digunakan untuk mengukur hasil belajar siswa.

d. Observasi
Observasi yang dimaksud dalam penelitian ini adalah untuk mengamati dan melihat situasi, interaksi, peran, dan perilaku sosial yang terjadi, peneliti mengamati objek secara seksama dengan melibatkan diri secara langsung dalam penelitian.

G. Instrumen Penelitian

Instrumen penelitian yang akan digunakan dalam penelitian ini adalah lembar observasi dan lembar kuisioner (angket) yang berisi pernyataan yang berhubungan dengan variabel penelitian yang harus dijawab oleh responden dan peneliti juga menggunakan pretest dan posttest untuk mengetahui peningkatan hasil belajar siswa.

H. Validasi Instrumen

Validasi merupakan tingkat kesahihan suatu instrumen. Suatu instrumen dikatakan valid apabila intrumen tersebut benar-benar mengukur apa yang hendak diukur. Intrumen penelitian tindakan kelas ini menggunakan pengujian validitas isi yang dilakukan oleh validator.

I. Teknik Analisis Data

Teknik analisis data yang digunakan dalam penelitian ini adalah teknik analisis statistik deskriptif. Analisis deskriptif ini digunakan untuk mengolah dan mengetahui sejauh mana penerapan tutor sebaya dalam implementasi strategi CIRC yang digunakan terhadap hasil belajar siswa pada mata pelajaran Sistem Komputer, dengan menggunakan skor tes hasil belajar. Selanjutnya dianalisis dengan menggunakan rumus persamaan:

Menghitung nilai pencapaian KKM

Pencapaian KKM $=\frac{\text { jumlah soal yang benar }}{\text { banyaknya soal }} \times 100$

KKM pada mata pelajaran Sistem Komputer $=75$

Untuk mencari nilai rata-rata menggunakan rumus persamaan.

$$
\text { Mean }=\frac{\mathrm{x} 1+\mathrm{x} 2+\mathrm{x} 3+\ldots+\mathrm{xn}}{\mathrm{N}} \times 100 \%
$$

Keterangan:

$\begin{array}{ll}\text { Mean } & : \text { Rata-rata } \\ \mathrm{x} 1 \ldots . . . \mathrm{xn} & : \text { Jumlah nilai siswa } \\ \mathrm{N} & : \text { Jumlah siswa }\end{array}$

Untuk mencari nilai ketuntasan hasil belajar siswa menggunakan rumus persentase ketuntasan klasikal dengan persamaan.

$$
\mathrm{P}=\frac{n}{N} \times 100
$$

Keterangan:

$\mathrm{P}=$ Persentase yang diperoleh

$\mathrm{n}=$ Jumlah siswa yang tuntas

$\mathrm{N}=$ Jumlah seluruh siswa

\section{J. Indikator Keberhasilan}

Indikator keberhasilan dalam penelitian ini adalah apabila skor rata-rata hasil belajar siswa/ketuntasan siswa mengalami peningkatan selama proses pembelajaran. Dalam aspek hasil belajar ditandai dengan peningkatan dengan skor minimum 75 dan ketuntasan secara klasikal yaitu $80 \%$ dari jumlah siswa yang tuntas belajar. 


\section{HASIL PENELITIAN}

A. Hasil Penelitian

1. Kegiatan Pra-Tindakan

Kegiatan Pra-Tindakan yang dilakukan yaitu dengan diadakan tes awal untuk mengetahui kemampuan kognitif siswa kelas X TKJ terhadap materi yang di ajarkan. Pemberian tes awal ini dimaksudkan sebagai acuan awal untuk mengetahui seberapa besar peningkatan hasil belajar sistem komputer siswa kelas $\mathrm{X}$ TKJ SMK Negeri 5 Makassar selama metode tutor sebaya dan strategi CIRC diterapkan. Dari hasil tes awal ini, peneliti juga dapat menentukan siapa yang akan menjadi tutor dalam kelompok pembelajaran nantinya.

2. Kegiatan Pelaksanaan Tindakan

\section{Siklus I dan Siklus II}

\section{a. Perencanaan (Planning)}

1) Pada tahap perencanaan tindakan, peneliti dan guru pengampu mata pelajaran Sistem Komputer berkolaborasi untuk menyiapkan materi yang akan disampaikan kepada siswa kelas X TKJ.

2) Menerapkan tutor sebaya dan strategi $C I R C$ sebagai solusi pemecahan masalah pembelajaran.

3) Membuat skenario pembelajaran yang meliputi: RPP, Handout materi dan LKPD sistem komputer dan alat evaluasi (soal pretest dan posttest).

4) Menyiapkan power point sebagai media pembelajaran.

5) Memilih dan menetapkan 6 orang tutor dari siswa kelas $\mathrm{X}$ TKJ.

6) Membagi anggota kelas menjadi 6 kelompok belajar saat proses pembelajaran,masing-masing kelompok terdiri dari 5-6 siswa dan 1 tutor yang sekaligus menjadi ketua kelompok. Sambil mengkondisikan kelas menjadi kelompok-kelompok, guru mengecek kesiapan tutor.

7) Menyiapkan peralatan-peralatan untuk mendokumentasikan kegiatan selama proses pembelajaran berlangsung.

\section{b. Tindakan (action)}

Siklus I dilakukan sejak bulan Oktober 2019. Pada Siklus I dilaksanakan selama 3 kali pertemuan. Siklus II dilakukan sejak bulan November 2019. Pada Siklus II dilaksanakan selama 3 kali pertemuan. Dalam penelitian ini, peneliti bertindak sebagai guru pengampu mata pelajaran Sistem Komputer untuk menerapkan metode tutor sebaya dan strategi $C I R C$.

\section{c. Observasi (Observing)}

Pada setiap pertemuan, pengamatan dilakukan sejak awal sampai akhir pembelajaran menggunakan lembar observasi.

d. Analisis data Siklus I dan Siklus II

1) Analisis Hasil Tes

Tabel 1. Analisis Hasil Pretest dan Postest I

\begin{tabular}{|c|c|c|c|c|}
\hline $\begin{array}{c}\text { No } \\
.\end{array}$ & Penilaian & $\begin{array}{c}\text { Siswa } \\
\text { tuntas }\end{array}$ & $\begin{array}{c}\text { Siswa tidak } \\
\text { tuntas }\end{array}$ & Persentase \\
\hline 1. & Pretest & 9 & 25 & $26 \%$ \\
\hline 2. & Postest & 11 & 23 & $32 \%$ \\
\hline
\end{tabular}

Tabel 2. Analisis Hasil Pretest dan Postest II

\begin{tabular}{|c|c|c|c|c|}
\hline $\begin{array}{c}\text { No } \\
\cdot\end{array}$ & Penilaian & $\begin{array}{c}\text { Siswa } \\
\text { tuntas }\end{array}$ & $\begin{array}{c}\text { Siswa tidak } \\
\text { tuntas }\end{array}$ & Persentase \\
\hline 1. & Pretest & 13 & 21 & $38 \%$ \\
\hline 2. & Postest & 21 & 13 & $62 \%$ \\
\hline
\end{tabular}

Tabel 3. Analisis Hasil Pretest dan Postest Siklus II

\begin{tabular}{|c|c|c|c|c|}
\hline No. & Penilaian & $\begin{array}{c}\text { Siswa } \\
\text { tuntas }\end{array}$ & $\begin{array}{c}\text { Siswa tidak } \\
\text { tuntas }\end{array}$ & Persentase \\
\hline 1. & Pretest & 24 & 10 & $71 \%$ \\
\hline 2. & Postest & 29 & 5 & $85 \%$ \\
\hline
\end{tabular}

2) Analisis Hasil Obsevasi

Tabel 4. Analisis Hasil Observasi Siklus I

\begin{tabular}{|c|c|c|c|c|c|c|c|c|}
\hline \multirow{3}{*}{ No. } & \multirow{3}{*}{ Aspek yang dinilai } & \multicolumn{6}{|c|}{ Pertemuan } & \multirow{3}{*}{$\begin{array}{l}\text { Rata- } \\
\text { rata }\end{array}$} \\
\hline & & \multicolumn{2}{|c|}{1} & \multicolumn{2}{|c|}{2} & \multicolumn{2}{|r|}{3} & \\
\hline & & $n$ & $\%$ & $n$ & $\%$ & $n$ & $\%$ & \\
\hline 1 & $\begin{array}{l}\text { Memperhatikan penjelasan } \\
\text { materi dari guru }\end{array}$ & 12 & $35 \%$ & 15 & $44 \%$ & 18 & $53 \%$ & $44 \%$ \\
\hline 2 & $\begin{array}{l}\text { Berani menjawab } \\
\text { pertanyaan dari guru }\end{array}$ & 2 & $6 \%$ & 3 & $9 \%$ & 6 & $18 \%$ & $11 \%$ \\
\hline 3 & $\begin{array}{l}\text { Memperhatikan penjelasan } \\
\text { materi tutor sebaya }\end{array}$ & 17 & $50 \%$ & 18 & $53 \%$ & 22 & $65 \%$ & $56 \%$ \\
\hline 4 & $\begin{array}{l}\text { Dapat mengemukakan } \\
\text { pendapat saat diskusi }\end{array}$ & 6 & $18 \%$ & 6 & $18 \%$ & 5 & $15 \%$ & $17 \%$ \\
\hline 5 & Jumlah siswa yang hadir & 34 & $100 \%$ & 34 & $100 \%$ & 34 & $100 \%$ & $100 \%$ \\
\hline
\end{tabular}

Tabel 5. Analisis Hasil Observasi Siklus II

\begin{tabular}{|c|c|c|c|c|c|c|}
\hline \multirow{2}{*}{ No. } & \multirow{2}{*}{ Aspek yang dinilai } & \multicolumn{4}{|c|}{ Penilaian } & \multirow{2}{*}{$\begin{array}{c}\text { Rata- } \\
\text { rata }\end{array}$} \\
\hline & & $n$ & $\%$ & $n$ & $\%$ & \\
\hline 1 & $\begin{array}{l}\text { Memperhatikan penjelasan } \\
\text { materi dari guru }\end{array}$ & 25 & $74 \%$ & 26 & $76 \%$ & $75 \%$ \\
\hline 2 & $\begin{array}{c}\text { Berani menjawab pertanyaan dari } \\
\text { guru }\end{array}$ & 10 & $29 \%$ & 12 & $35 \%$ & $32 \%$ \\
\hline 3 & $\begin{array}{l}\text { Memperhatikan penjelasan } \\
\text { materi tutor sebaya }\end{array}$ & 26 & $76 \%$ & 25 & $74 \%$ & $75 \%$ \\
\hline 4 & $\begin{array}{c}\text { Dapat mengemukakan pendapat } \\
\text { saat diskusi }\end{array}$ & 6 & $18 \%$ & 5 & $15 \%$ & $16 \%$ \\
\hline 5 & Jumlah siswa yang hadir & 34 & $100 \%$ & 34 & $100 \%$ & $100 \%$ \\
\hline & Persentase & & & 3. & & \\
\hline
\end{tabular}

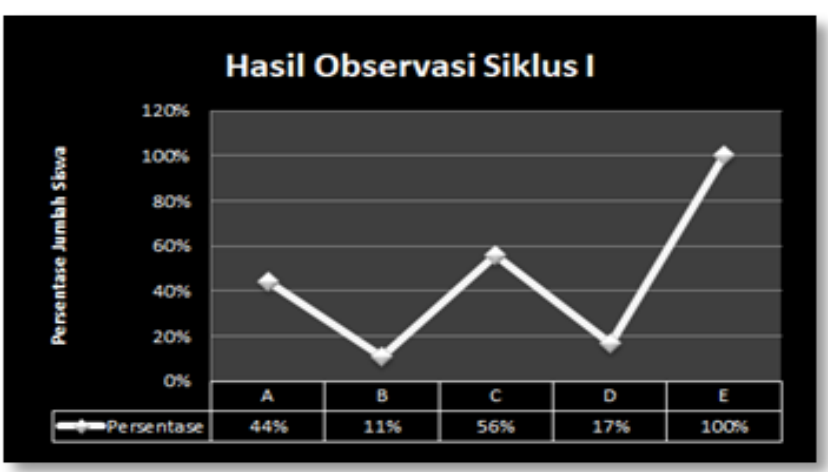

Gambar 3. Grafik Persentase Hasil Observasi Siklus I

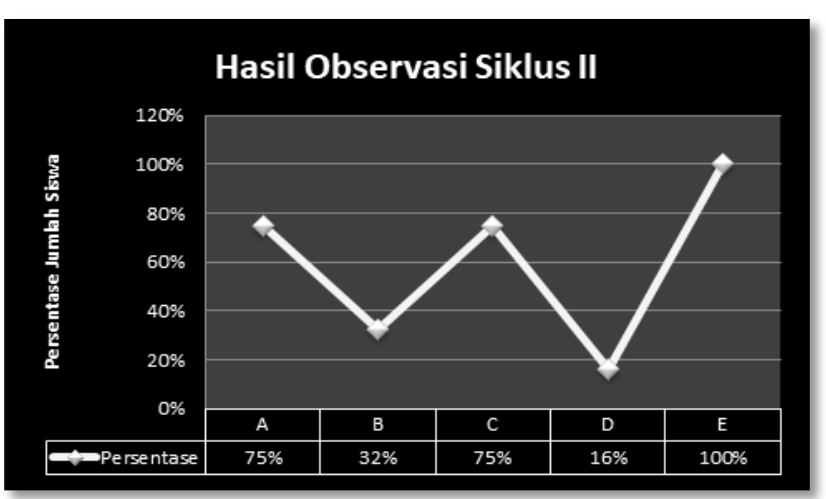

Gambar 4. Grafik Persentase Hasil Observasi Siklus II

Peningkatan hasil belajar siswa dari Pra-Tindakan sampai Siklus II dapat ditunjukkan pada tabel dan diagram berikut: 
Tabel 6. Peningkatan Hasil Belajar Siswa

\begin{tabular}{|c|c|c|c|}
\hline Siklus & $\begin{array}{c}\text { Jumlah } \\
\text { Siswa }\end{array}$ & $\begin{array}{c}\text { Jumlah } \\
\text { Siswa } \\
\text { Tuntas }\end{array}$ & Persentase \\
\hline Pra-Tindakan & 32 & 6 & $19 \%$ \\
\hline Siklus I & 34 & 21 & $62 \%$ \\
\hline Siklus II & 34 & 29 & $85 \%$ \\
\hline
\end{tabular}

Tabel 7. Rekapitulasi Peningkatan Hasil Belajar Siklus I dan Siklus II

\begin{tabular}{|c|c|c|c|c|}
\hline Siklus & $\begin{array}{c}\text { Jumlah } \\
\text { Siswa }\end{array}$ & $\begin{array}{c}\text { Jumlah } \\
\text { Siswa } \\
\text { Tuntas }\end{array}$ & $\%$ & $\begin{array}{c}\text { Besar } \\
\text { Peningkatan } \\
\text { yang Terjadi }\end{array}$ \\
\hline Siklus I & \multirow{2}{*}{34} & 21 & $62 \%$ & $23 \%$ \\
\cline { 1 - 3 } Siklus II & & 29 & $85 \%$ & \\
\hline
\end{tabular}

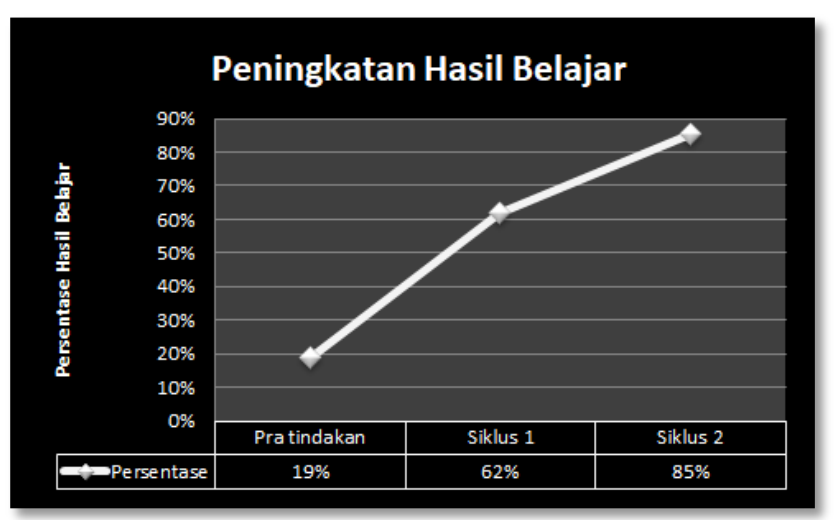

Gambar 5. Grafik Peningkatan Hasil Belajar

\section{B. Pembahasan}

Pembelajaran Tutor Sebaya memberikan kesempatan kepada siswa untuk belajar dan bekerjasama dalam kelompok kecil terutama dalam hal kemampuan akademiknya. Dengan pembelajaran Tutor Sebaya, siswa dapat berinteraksi sekaligus menyadari perbedaan manusia sebagai makhluk sosial dan juga pentingnya mata pelajaran sistem komputer.

Proses awal pelaksanaan dari metode tersebut adalah pada Siklus I pertemuan 1 diberikan tes untuk mengukur kemampuan siswa terhadap materi terkait. Kemudian dari hasil tersebut dilanjutkan dengan pembentukan kelompok yang mana anggotanya dipilih berdasarkan nilai tes dari hasil kerja masingmasing siswa sehingga setiap kelompok mempunyai kemampuan anggota yang sama. Ketua kelompok dipilih dari hasil test yang mempunyai nilai tertinggi. Ketua kelompok bertugas mengkoordinir, memonitor, dan membimbing anggotanya dalam mengerjakan tugas serta memberikan penjelasan kepada anggotanya atas kesulitan-kesulitan yang mereka alami ketika mengerjakan soal. Ketua kelompok bertanggung jawab penuh atas hasil kerja kelompok dan pemahaman anggotanya terhadap materi terkait. Dalam tahap berkelompok ketua kelompok juga membagi tugas dengan beban yang berbeda-beda dari soal dan materi yang disampaikan secara bergantian dari segi bobot soal hingga metode dari pengerjaan soal materi terkait. Hal ini dimaksudkan agar setiap anggota kelompok akan mendapatkan hasil dan pemahaman yang sama terhadap materi yang sedang dibahas.

Setiap pertemuan dan langkah-langkah metode pada penelitian ini diawali dengan memberikan pertanyaan tentang materi yang akan dipelajari yang bertujuan untuk menggali pengetahuan awal siswa terhadap materi tersebut. Kemudian dilanjutkan dengan kegiatan inti pembelajaran yaitu dimulai dengan membagikan LKPD. Setelah diskusi kelompok berakhir, diadakan presentasi hasil diskusi oleh masing-masing kelompok. Sebelum proses pembelajaran berakhir, siswa diberi postest untuk mengetahui sejauh mana keberhasilan tindakan yang dilaksanakan. Penghargaan kelompok terbaik dengan nilai ratarata yang paling tinggi diumumkan pada pertemuan berikutnya. Hasil analisis pada setiap tahap menunjukkan adanya peningkatan prestasi belajar terhadap materi relasi logik dan fungsi gerbang dasar. Hal ini terlihat dari hasil Postest.

Pada Siklus I pertemuan 1 untuk Pretest ketuntasan belajar secara klasikal memiliki presentase sebesar 26\%, dimana dari 34 siswa, 9 siswa dinyatakan telah tuntas belajar dan 25 siswa belum tuntas belajar. Pada pertemuan 2 setelah diadakan Postest ketuntasan belajar klasikal mengalami peningkatan sebesar 32\%, meskipun belum dikatakan memenuhi standar yang ditetapkan, dimana dari 34 siswa, hanya 11 siswa telah tuntas belajar sedangkan 23 siswa belum tuntas belajar. Sebelum memasuki pertemuan selanjutnya, masing-masing dari ketua kelompok telah diberikan materi atau handout materi yang akan dibahas pada pertemuan berikutnya untuk dipelajari di rumah masing-masing. Pada pertemuan 3, sebelum memasuki pembahasan materi terlebih dahulu diberikan Pretest II. Setelah diadakan Pretest, ketuntasan belajar secara klasikal memiliki presentase sebesar 38\%, dimana dari 34 siswa 13 siswa dinyatakan telah tuntas belajar, dan 21 siswa belum tuntas belajar. Pada pertemuan III ini juga diadakan Postest ketuntasan belajar klasikal dan mengalami peningkatan sebesar $62 \%$, meskipun juga belum dikatakan memenuhi standar yang ditetapkan yaitu sebesar $80 \%$, dimana dari 34 siswa, hanya 21 siswa telah tuntas belajar sedangkan 13 siswa lainnya belum tuntas belajar. Oleh karena itu, pada penelitian ini akan dilanjutkan ke Siklus II untuk mencapai indikator keberhasilan yang telah ditetapkan sebelumnya.

Pada Siklus II pertemuan 1 untuk Pretest ketuntasan belajar secara klasikal memiliki presentase sebesar $71 \%$, dimana dari 34 siswa, 24 siswa dinyatakan telah tuntas belajar dan 10 siswa belum tuntas belajar. Pada pertemuan 2 setelah diadakan Postest ketuntasan belajar klasikal mengalami peningkatan sebesar $85 \%$, dimana dari 34 siswa, sebanyak 29 siswa telah tuntas belajar sedangkan sisa 5 siswa belum tuntas belajar. Sehingga ketuntasan klasikal pada hasil evaluasi di Siklus II ini dikatakan telah tercapai sebab besar peningkatan yang terjadi dari Siklus I ke Siklus II yaitu sebesar 23\%, Berdasarkan data tersebut diatas, dapat disimpulkan bahwa penerapan pembelajaran Tutor Sebaya dan strategi CIRC dapat meningkatkan hasil belajar siswa. Demikian juga aktivitas belajar siswa mengalami peningkatan, hasil observasi siswa pada Siklus I ke Siklus II mengalami peningkatan.

Berdasarkan data tersebut diatas, dapat disimpulkan bahwa penerapan pembelajaran Tutor Sebaya dan strategi CIRC pada mata pelajaran Sistem Komputer dapat meningkatkan hasil belajar siswa.

\section{KESIMPULAN}

A. Kesimpulan

Berdasarkan hasil penelitian tindakan kelas yang diperoleh, maka dapat disimpulkan:

Penerapan tutor sebaya dalam implementasi strategi CIRC dapat meningkatkan hasil belajar siswa kelas X TKJ pada mata pelajaran sistem Komputer. Hasil belajar siswa mulai dari pra tindakan hingga Siklus II setelah menerapkan tutor sebaya dalam implementasi strategi CIRC dapat meningkat sebesar $85 \%$. Pada siklus I hasil belajar siswa sudah meningkat namun peningkatan persentase hasil belajar siswa belum mencapai nilai KKM yang telah ditentukan yaitu 75 sehingga dibutuhkan pelaksanaan siklus 
II. Pada siklus II hasil belajar siswa telah mencapai nilai KKM yang telah ditentukan. Hal ini menandakan bahwa penelitian ini telah berhasil dan siklus dihentikan.

B. Saran

Berdasarkan hasil pembahasan dan kesimpulan di atas, berikut disampaikan beberapa saran yang dapat dijadikan bahan pertimbangan dalam rangka perbaikan pembelajaran ke arah yang lebih baik, yaitu:

1. Bagi guru

a) Dalam melaksanakan pembelajaran, guru sebaiknya menggunakan metode dan strategi pembelajaran yang bervariasi agar siswa tidak bosan atau jenuh sehingga berdampak pada hasil belajar siswa yang lebih baik.

b) Guru dapat menggunakan pembelajaran dalam berkelompok untuk memberi kesempatan lebih besar kepada siswa guna menuangkan pendapatnya sehingga siswa dapat ikut berperan aktif dalam suatu proses pembelajaran.

2. Bagi Siswa

a) Siswa diharapkan dapat memberi dukungan penuh terhadap guru untuk mengembangkan berbagai variasi metode dan strategi pembelajaran yang diterapkan di dalam kelas.

b) Siswa perlu meningkatkan kemampuan belajarnya terutama dalam menghadapi kesulitan, bekerja kelompok, mencari dan memecahkan masalah pada soal-soal serta melaksanakan tugas-tugas yang diberikan guru.

\section{DAFTAR PUSTAKA}

[1] Andriyansah dkk. (2014). "Menjadi Tutor Sebaya Terampil dan Profesional". Yogyakarta : Graha Ilmu.

[2] Arikunto, S., Suhardjono., Supardi. 2015. "Penelitian Tindakan Kelas". Jakarta: PT. Bumi Aksara.

[3] Fatmawati, Sri. 2018. "Penerapan Pembelajaran Model Cooperative Integrated Reading And Composition (CIRC) Berbantuan Website Blogspot Pada Mata Kuliah Metodologi Penelitian Pendidikan Fisika". Palangkaraya: IAIN Palangkaraya. Skripsi.

[4] Fitrianto, A.M. 2018. "Penerapan Metode Tutor Sebaya Untuk Meningkatkan Hasil Belajar Siswa Kelas X TKR A Pada Mato Pelajaran Teknologi Dasar Otomotif Di SMK Muhammadiyah 1 Salam”. Yogyakarta: Universitas Negeri Yogyakarta. Skripsi.

[5] Halimah, Andi. 2014. "Metode Cooperative Integrated Reading And Composition (CIRC) dalam Pembelajaran Membaca dan Menulis di SD/MI". Auladuna. Volume 1, Nomor 1. Hlm. 27-35. Makassar: UIN Alauddin.

[6] Hartono, Rudi. 2013. "Ragam Model Mengajar yang Mudah Diterima Murid”. Jogjakarta: Diva Press.

[7] Hendriana, H. \& Afrilianto, M. 2014. "Panduan bagi Guru Penelitian Tindakan Kelas Suatu Karya Tulis Ilmiah”. Bandung: PT. Refika Aditama.

[8] Kemmis \& Mc. Taggart. 2010. "The Action Research Planner" Geelong: Deaken Univercity Press.

[9] Mangesa, R. T., \& Mappaloteng, A. M. 2019. Mengoptimalkan kualitas proses pembelajaran melalui pembelajaran kooperatif dengan Penelitian Tindakan Kelas. Jurnal Seminar Nasional Pengabdian Kepada Masyarakat. (Di akses pada tanggal 26 Januari 2020).

[10] Mappeasse, M. Y. 2009. Pengaruh Cara dan Motivasi Belajar Terhadap Hasil Belajar Programmable Logic Controller (PLC) Siswa Kelas III Jurusan Listrik SMK Negeri 5 Makassar. Jurnal Medtek, 1(2), 1-6.

[11] Nana Sudjana. 2014. "Penilaian Hasil Proses Belajar Mengajar". Bandung: PT. Remaja Rosdakarya.

[12] Pramesti, Riska Dian. (2014). "Peningkatan Hasil Belajar Siswa Dengan Penerapan Metode Pembelajaran Peer Teaching (Tutor Sebaya) Pada Mata Pelajaran Dasar Kepariwisataan Kelas X JB 3 di SMKN 3 Magelang”. Skripsi. Yogyakarta: Universitas Negeri Yogyakarta.
[13] Rustantini, Dewi Fitri. 2013. "Implementasi Strategi Cooperative Integrated Reading And Composition (CIRC) Untuk Meningkatkan Keterampilan Membaca dan Menemukan Ide Pokok Pada Mata Pelajaran Bahasa Indonesia Kelas IV Sd Negeri 1 Pule Tahun 2012/2013". Jawa Tengah: Universitas Muhammadiyah Surakarta. Skripsi.

[14] Sanjaya, Wina. 2013. Strategi Pembelajaran Berorientasi Standar Proses

Pendidikan. Jakarta: Kencana.

[15] Sari, Feni Desna. 2014. Studi Perbandingan Prestasi Belajar Peserta Didik Kelas VII yang Diterima Melalui Jalur Bina Lingkungan dan Non Bina Lingkungan di SMPN 9 Bandar Lampung Tahun Ajaran 2013/2014. Bandar Lampung: Universitas Lampung. Skripsi.

[16] Schunk, D. H. (2012). "Learning Theories: An Education Perspective (Teori-teori Pembelajaran:Perspektif Pendidikan Edisi Keenam)”. (Terjemahan oleh: Eva Hamdiah, Rahmat Fajar). Yogyakarta: Pustaka Pelajar.

[17] Silberman, Melvin L. 2019. “Active Learning, 101 Cara Belajar Siswa Aktif Edisi Revisi". Bandung: Nuansa Cendekia.

[18] Slavin, R. E. (2010). "Cooperative Learning Teori, Riset dan Praktik". Bandung: Nusa Media.

[19] Slavin, R. E. 2016. “Cooperative Learning: Teori Riset dan Praktik". Bandung: Nusa Media.

[20] Sugiyono. 2011. Metode Penelitian Kuantitatif, Kualitatif dan R\&D. Bandung: Afabeta.

[21] Sugiyono. 2013. "Metode Penelitian Kuantitatif, Kualitatif dan $R \& D$ ". Bandung: Alfabeta.CV.

[22] Sugiyono. 2015. "Metode Penelitian Kombinasi (Mix Methods)". Bandung: Alfabeta.

[23] Sujarweni, W. V. 2014. "Metodologi Penelitian”. Yogyakarta: PT. Pustaka Baru.

[24] Sutarno, H., Ali Nurdin, E., Awalani, I. 2010. "Penerapan Model Pembelajaran Cooperative Integrated Reading And Composition (CIRC) Berbasis Komputer untuk Meningkatkan Hasil Belajar Siswa pada Pembelajaran TIK". PTIK 3 (1): 1-5. Bandung: Universitas Pendidikan Indonesia.

[25] UU RI NO. 20 Tahun 2003. "Sistem Pendidikan Nasional 8 Juli 2003 Lembaran Negara Republik Indonesia Tahun 2003 Nomor 4301. Jakarta. (Online). Tersedia pada: https://kemenag.go.id/file/dokumen/UU2003.pdf. Diakses tanggal 1 Juli 2019.

[26] Zain. \& Djamarah, B. (2014). "Strategi Belajar Mengajar". Jakarta: Rineka Cipta. 